\title{
The Effect of MHealth to Increase Mother's Skill in Children Growth and Development Monitoring During $>36-48$ and $>48-60$ Months
}

\author{
$1^{\text {st }}$ Maria Ulfah Kurnia Dewi \\ Program Bachelor of Midwifery \\ Universitas Muhammadiyah Semarang \\ Semarang, Indonesia \\ mariaulfahkd82@gmail.com
}

\author{
$2^{\text {nd }}$ Nova Linda Rambe \\ Program Bachelor of Midwifery \\ Universitas Imelda Medan \\ Medan, Indonesia \\ rambenovalinda@gmail.com
}

\begin{abstract}
Obstacles encountered the lack of implementation of early detection of growth and development of children during $>36-48$ and $>48-60$ months, especially in the development conducted every six months. Children at this age are rarely or never visit Integrated Healthcare Center anymore because the child has entered Early Childhood Education and mother perception that the child has been given compulsory immunization and no need to visit Integrated Healthcare Center. The problem of under five-year growth occurred in Indonesia (2013) is underweight $19.6 \%$, stunting $37.2 \%$, wasting $5.3 \%$, and childhood developmental problems occurred based on the study is $30 \%$. This study aims to assess the effect of the application of MHealth on improving the skills of mothers in monitoring the growth and development of children during $>36$ 48 and $>48-60$ months. This study is aimed to analyze the effect of MHealth to increase mother's skill in children's growth development monitoring during $>36-48$ and $>48-60$ months with mothers and midwives for control design in each group by using simple random sampling for sampling technique for maternal and total sampling for midwives. The sample is determined based on age, education, occupation, income, and some children showing no significant difference between the control and treatment groups $(p>0.05)$. This study uses Quasi-Experimental research design, pre and post-test research design with control group design, which is to assess the effect of MHealth to improve maternal skills in monitoring the growth and development of children during $>36-48$ and $>48-60$ months. Data analysis is taken by Wilcoxon and Mann Whitney. The analysis showed that MHealth effects to increase mother's skill in children's growth development monitoring during $>36-48$ and $>48-60$ months $(\mathbf{p}<0.05)$.
\end{abstract}

Keywords-MHealth, Growth Development, Mother's skill, $>36-48$ and $>48-60$ months

\section{INTRODUCTION}

The success of monitoring implementation or early detection and stimulation of growth and development of under five years is inseparable from the role of health workers and parents, especially mothers[1]. Riset Kesehatan Dasar (Riskesdas) 2013 data reported a stunting prevalence (height per age) of 37.2 percent consisting of 18.0 percent very stunting and 19.2 percent stunting. While the prevalence of very wasting (body weight per height) nationally in 2013 was still quite high at 5.3 percent, there was a decrease compared to $2010(6.0 \%)$ and in $2007(6.2 \%)$ [2]. This study aims to assess the effect of the application of MHealth on improving the skills of mothers in monitoring the growth and development of children during $>36-48$ and $>48-60$ months. The health efforts undertook aim to maintain their survival while improving children's life quality to achieve optimal physical, mental, emotional, and social growth and development[3]. Factors influencing child developmental growth problems are poverty, malnutrition, unhealthy lifestyles, mother's low knowledge, lack of use Integrated Healthcare Center, low coverage of children under five years who are weighed, lack of stimulation, lack of parental love, lack of health information centers, lack of adequate services health[2],[4], [5]. Developmental growth problems that occur at under five years can be early detected if regularly monitored so it is necessary to monitor the growth of under five years of development to detect disorders early so that the problem does not become more severe[6].

MHealth in this study contains guidelines for monitoring the growth of children's development divided into 8 stages modules, according to the age of the stages of developmental growth during 36-48 months and 48-60 months. MHealth is proposed as an alternative media in monitoring children's growth and development to improve skills in monitoring children's growth and development. Research also provides evidence related to skills through skills in personal health maintenance that integrate motivation, self-empowerment, patient encouragement in making decisions, and responsibility for maintaining personal[7],[8].

\section{RESEARCH METHODS}

\section{A. Methods}

The study design is Quasi-Experimental by comparing between the treatment group and the conventional group. In both groups, skills assessment will be carried out before and after treatment (pretest-posttest control group design)[9]. The instrument used to measure skills is the skills questionnaire.

\section{B. Sample design}

By simple random sampling, we selected the subjects of this study had inclusion criteria: mothers who were 25-35 years old, mothers who were physically and mentally healthy, mothers who had children during $>36-48$ and $>48-60$ months, mothers who have children born at term and normal birth weight $>2500$ grams, mothers who can read and write, mothers who have lived with children for at least the last 1 month, mothers and midwives who have an Android-based 
smartphone with a system that has a minimum specification of Android device version 4.0.4 (Ice Cream Sandwich), mothers who live in internet facilities, midwives who work in the Babakansari area Kiaracondong districts Bandung city and willing to be a respondent. Exclusion criteria were mothers who had children with a history of complications, mothers who had children with congenital abnormalities, mothers who were not present at the time of the study, midwives in the absence of leave, and midwives who were not present at the time of the study. The sample is determined based on age, education, occupation, income, and some children showing no significant difference between the control and treatment groups ( $\mathrm{p}>0.05)$.

\section{Data collection}

Data collection in this study was conducted on mothers who have children during $>36-48$ and $>48-60$ months who are in the work area of Babakansari Kiaracondong Public Health Center in Bandung to get an assessment of the effect of MHealth implementation on improving mother's skills in monitoring the growth and development of children aged $>$ $36-48$ and $>48-60$ months. The research subjects were invited on the appointed day at the pre-determined inspection site then the study subjects were divided into treatment and control groups and given socialization regarding technical guidelines for monitoring child growth and development by applying KIA book and MHealth. The next step is to do a pretest to get the value of maternal skills in monitoring the growth and development of children during $>36-48$ and $>48$ 60 months. Then the treatment group is given an intervention namely the use of MHealth, while the control group is given the intervention to use the KIA book media for growth and development monitoring of children during $>36-48$ and $>48$ 60 months. The last step is to do a post-test to get the value of the effect of using MHealth on improving mother's skills in monitoring the growth and development of children during $>36-48$ and $>48-60$ months.

\section{DATA ANALYSIS}

Respondent Characteristics of Children Age >36-48 months

TABLE 1. RESPONDENT CHARACTERISTIC OF CHILDREN AGE $>36-48$ MONTHS

\begin{tabular}{|l|c|c|c|c|c|}
\hline \multirow{2}{*}{ Characteristic } & \multicolumn{3}{|c|}{ Group } & \multirow{2}{*}{ p value* } \\
\cline { 2 - 5 } & \multicolumn{2}{|c|}{ Control } & \multicolumn{2}{|c|}{ Treatment } & \\
\cline { 2 - 5 } & $\mathrm{n}=38$ & $\%$ & $\mathrm{n}=38$ & $\%$ & 0,497 \\
\hline Age & 1 & 2,63 & 1 & 2,63 & \\
$<20$ years & 33 & 86,8 & 31 & 81,6 & \\
20-35 years & 4 & 10,5 & 6 & 15,8 & \\
$>35$ years & & & & & \multirow{2}{*}{0,634} \\
Number of children & & & & & \\
Have 1 child & 13 & 34,2 & 15 & 39,5 & \\
Have >1 children & 25 & 65,8 & 23 & 60,5 & \\
& & & & & \multirow{2}{*}{0,807} \\
Level of education & & & & & \\
Elementary school & 1 & 2,63 & 2 & 5,26 & \\
Junior high school & 11 & 28,9 & 11 & 28,9 & \\
Senior high school & 23 & 60,5 & 23 & 60,5 & \\
College & 3 & 7,89 & 2 & 5,26 & \multirow{2}{*}{0,783} \\
Employment & & & & & \\
Haven't work & 29 & 76,3 & 30 & 78,9 & \\
Work & 9 & 23,7 & 8 & 21,1 & \\
& & & &
\end{tabular}

\begin{tabular}{|l|c|c|c|c|c|}
$\begin{array}{l}\text { Income } \\
\text { <Regional minimum } \\
\text { payment }\end{array}$ & 15 & 39,5 & 15 & 39,5 & 0,250 \\
$\begin{array}{l}\geq \text { Regional minimum } \\
\text { payment }\end{array}$ & 23 & 60,5 & 23 & 60,5 & \\
\hline
\end{tabular}

Based on table 1 it appears that the mother's characteristics of children $>36-48$ months (age, number of children, level of education, employment, income) are not significant differences with $\mathrm{p}$ values $>0.05$. The characteristics of the two groups are considered homogeneous so that both groups are worth comparing.

\section{A. Respondent Characteristics of Children Aged >48-60 months}

TABLE 2. RESPONDENT CHARACTERISTIC OF CHILDREN AGED $>48-60$ MONTHS

\begin{tabular}{|c|c|c|c|c|c|}
\hline \multirow[t]{3}{*}{ Characteristic } & \multicolumn{4}{|c|}{ Group } & \multirow{3}{*}{$\begin{array}{c}\mathrm{p} \\
\text { value* }\end{array}$} \\
\hline & \multicolumn{2}{|c|}{ Control } & \multicolumn{2}{|c|}{ Treatment } & \\
\hline & $\mathrm{n}=37$ & $\%$ & $\mathrm{n}=37$ & $\%$ & \\
\hline Age & & & & & \\
\hline $20-25$ years & 8 & 21,6 & 6 & 16,2 & 0,371 \\
\hline$>25-30$ years & 13 & 35,1 & 19 & 51,4 & \\
\hline$>30-35$ years & 16 & 43,3 & 12 & 32,4 & \\
\hline Number of children & & & & & \\
\hline Have 1 child & 21 & 56,8 & 14 & 37,8 & 0,103 \\
\hline Have $>1$ children & 16 & 43,2 & 23 & 62,2 & \\
\hline Level of education & & & & & \\
\hline Elementary school & 7 & 19.0 & 7 & 19,0 & 0,704 \\
\hline Junior high school & 11 & 29.7 & 8 & 21,6 & \\
\hline Senior high school & 12 & 32,4 & 11 & 29,7 & \\
\hline College & 7 & 18,9 & 11 & 29,7 & \\
\hline Employment & & & & & \\
\hline Haven't work & 20 & 54,1 & 21 & 56.8 & 0,815 \\
\hline Work & 17 & 45,9 & 16 & 43,2 & \\
\hline Income & & & & & \\
\hline $\begin{array}{l}<\text { Regional minimum } \\
\text { payment }\end{array}$ & 20 & 54,1 & 19 & 51,4 & 0,816 \\
\hline $\begin{array}{l}\geq \text { Regional minimum } \\
\text { payment }\end{array}$ & 17 & 45,9 & 18 & 48,6 & \\
\hline
\end{tabular}

Based on table 2 it appears that the mother's characteristics of children $>48-60$ months (age, number of children, level of education, employment, income) are not significant differences with $\mathrm{p}$ values $>0.05$. The characteristics of the two groups are considered homogeneous so that both groups are worth comparing.

B. The difference in Mother's skill scores (>36-48 months) Before and After Treatment

TABLE 3. THE DIFFERENCE IN MOTHER'S SKILL SCORES $(>36-48$ MONTHS) BEFORE AND AFTER TREATMENT

\begin{tabular}{|l|c|c|c|c|c|c|}
\hline \multirow{2}{*}{$\begin{array}{c}\text { Variabl } \\
\text { e }\end{array}$} & \multicolumn{2}{|c|}{ Control $(\mathrm{n}=38)$} & \multirow{2}{*}{$\begin{array}{c}\mathrm{p} \text { value } \\
*\end{array}$} & \multicolumn{2}{|c|}{ Treatment $(\mathrm{n}=38)$} & \multirow{2}{*}{$\begin{array}{c}\mathrm{p} \text { value } \\
*\end{array}$} \\
\cline { 2 - 3 } \cline { 5 - 6 } & Pre & Post & & Pre & Post & \\
\hline Mother's & & & $<0,001$ & & & $<0,001$ \\
skill & & & & & & \\
$(>36-48$ & & & & & & \\
months $)$ & & & & & & \\
Mean & 32,23 & 55,59 & & 33,00 & 76,64 & \\
(SD) & $(15,76)$ & $(11,91)$ & & $(11,10)$ & $(16,48)$ & \\
Median & 33,33 & 54,16 & & 33,33 & 70,83 & \\
Interval & $0-62,5$ & $41,67-$ & & $16,67-$ & $58,33-$ & \\
& & 83,33 & & 50 & 100 & \\
\hline
\end{tabular}


*Wilcoxon test

Based on table 3 , it was found that there were significant differences in the mother's skills scores of children aged $>36$ 48 months before and after treatment and control groups were given intervention with $\mathrm{p}$ values $<0.001$.

C. The difference in Mother's skill scores (>48-60 months) Before and After Treatment

TABLE 4. THE DIFFERENCE IN MOTHER'S SKILL SCORES (>48-60 MONTHS) BEFORE AND AFTER TREATMENT

\begin{tabular}{|c|c|c|c|c|c|c|}
\hline \multirow[t]{2}{*}{ Variable } & \multicolumn{2}{|c|}{ Control $(n=37)$} & \multirow{2}{*}{$\underset{*}{\mathrm{p} \text { value }}$} & \multicolumn{2}{|c|}{ Treatment $(n=37)$} & \multirow{2}{*}{$\begin{array}{c}\mathrm{p} \\
\text { value } \\
*\end{array}$} \\
\hline & Pre & Post & & Pre & Post & \\
\hline $\begin{array}{l}\text { Mother's } \\
\text { skill } \\
(>48-60 \\
\text { months) }\end{array}$ & & & 0,339 & & & $\begin{array}{c}0,00 \\
4\end{array}$ \\
\hline Mean (SD) & $\begin{array}{l}74,84 \\
(5,17)\end{array}$ & $\begin{array}{c}75,07 \\
(5,07)\end{array}$ & & $\begin{array}{l}75,16 \\
(5,40)\end{array}$ & $\begin{array}{l}79,01 \\
(4,96)\end{array}$ & \\
\hline Median & 72,82 & 72,82 & & 72,55 & 81,23 & \\
\hline Interval & $\begin{array}{l}67,1- \\
85,9\end{array}$ & $\begin{array}{c}68,5- \\
86,4\end{array}$ & & $\begin{array}{l}67,9- \\
83,4\end{array}$ & $\begin{array}{c}68,4- \\
84,5\end{array}$ & \\
\hline
\end{tabular}

Based on table 4, it was found that there was no significant difference in the mother's skills scores of children aged $>48$ 60 months in the control group before and after treatment with the control group $(p>0.05)$ and there was a significant difference in the mother's skill scores of children aged $>48$ 60 months in the treatment group before and after the control group was treated $(\mathrm{p}<0.05)$.

\section{The Increased Skill Scores After Treatment (>36-48 months)}

Table 5. The Increased Skill Scores After Treatment $(>36-$ 48 months)

\begin{tabular}{|l|c|c|c|}
\hline \multicolumn{1}{|c|}{ Variable } & \multicolumn{2}{|c|}{ Group } & \multirow{2}{*}{ p value * } \\
\cline { 2 - 3 } & $\begin{array}{c}\text { Control } \\
(\mathrm{n}=38)\end{array}$ & $\begin{array}{c}\text { Treatment } \\
(\mathrm{n}=38)\end{array}$ & \\
\hline Mother's skill & & & $<0,001$ \\
$(>36-48$ months $)$ & & & \\
Mean & $23,35(17,66)$ & 43,64 & \\
(SD) & 18,75 & $(21,40)$ & \\
Median & $-16,67-58,33$ & $12,50-83,33$ & \\
Interval & \multicolumn{2}{|l}{} \\
\hline
\end{tabular}

*) Mann Whitney test

Based on table 5 obtained an increase in the skills score in the treatment and control groups with $\mathrm{p}<0.001$. In the treatment group, an increase in skill scores was 43,64 while the control group was only 23,35

\section{E. The Increased Skill Scores After Treatment (>48-60 months)}

TABLE 6. THE INCREASED SKILL SCORES AFTER TREATMENT $(>48-60$ MONTHS)

\begin{tabular}{|l|c|c|c|}
\hline \multicolumn{1}{|c|}{ Variable } & \multicolumn{2}{|c|}{ Group } & \multirow{2}{*}{ p value * } \\
\cline { 2 - 3 } & $\begin{array}{c}\text { Control } \\
(\mathrm{n}=37)\end{array}$ & $\begin{array}{c}\text { Treatment } \\
(\mathrm{n}=37)\end{array}$ & \\
\hline Mother's skill & & & 0,013 \\
(>48-60 months) & & & \\
Mean (SD) & $0,24(5,53)$ & $3,86(7,54)$ & \\
Median & 0,00 & 2,5 & \\
Interval & $-13,71-13,77$ & $-14,01-13,36$ & \\
\hline
\end{tabular}

*) Mann Whitney test
Based on table 6 an increase in skills scores obtained in the intervention and control groups $(\mathrm{p}<0.05)$. In the intervention group, an increase in skill scores 3,86 while the control group only 0,24 .

\section{DISCUSSION}

Skills are abilities to do something well. Psychomotor domain is a goal related to the ability of a person's skills. The previous results research conducted by Jongh about Short Message Service (SMS) messages to facilitate self-health maintenance stated that smartphone applications, such as SMS and Multimedia Message Service (MMS) provide a sense of comfort, cost savings, support self-management, and improve health care skills patient self. In particular, self-management for long-term health care requires that someone has skills to monitor the symptoms and clinical value of a condition so that it can be adjusted to the appropriate medication, treatment, or health behavior. Text messaging can support personal health maintenance skills, and in this way increase the patient's confidence to carry out the desired health behavior[8].

Increased skills occur because of MHealth more interesting than the KIA book that contains a picture. According to the theory that visual information is received by the eye, transferred to the occipital cortex and interpreted by the area of visual association. The Human capacity to receive input and produce output is limited. The reality provides more input than can be accepted by human processing systems. Humans reduce input to some extent. Therefore the packaging of information greatly determines the capacity of information[10]. By the findings of Huifen and Francis that learning with animation is more effective and efficient than the ordinary image[11]. These findings reinforce the assumption that by using animation in MHealth can provide ease of understanding for users and the information conveyed is more inherent in the mind, to improve skills. This is evident from the results of the study that there is a relationship between the mother's skills regarding early detection of growth and development and child development[12]. Besides, research by Love SM, et al who said through a smartphone application, the mother is increasingly skilled in parenting[13].

The results of other previous studies indicate that the use of smartphones in conveying health information increase the skills and knowledge of individuals in maintaining personal health[14]. Long - term illnesses affect a significant proportion of the population in developed and developing countries. Mobile phone messaging applications, such as Short Message Service (SMS) and Multimedia Message Service (MMS), may present convenient, cost - effective ways of supporting self - management and improving patients' self - efficacy skills through, for instance, medication reminders, therapy adjustments or supportive messages[8]. In the previous systematic review, 20 RCTs were included to evaluate the effectiveness of mHealth apps for health-related behavior change. Seventeen studies among 20 showed a positive contribution to the enhancement of health-related behaviors. Some studies considered multiple function apps, such as entering data and providing feedback, education, and reminders. One study reported that having multiple app functions is much better to manage health status and to improve health-related behaviors[15]. The results of another overview can be used to develop a broad picture of the dimensions of nursing care that have the potential to be 
supported by MHealth. MHealth has a positive effect on health care. They can promote patient-centered health care, improve the quality of care, and educate health professionals and patients[16]. The reduction of childhood stunting is difficult to achieve by interventions that focus only on improving nutrition. Mobile phones are now successfully being used for behavior change communication to improve health. Mobile phones can potentially enable improved coverage of maternal and child health services in otherwise hard to reach rural areas, enable improvement in staff efficiency, and aid in better engagement of participants who have become accustomed to the use of mobile phones. It intends to achieve this outcome by improving nutrition practices, facilitating early recognition of illness, improve health care seeking behavior at the facilities for timely management of illnesses and improve personal hygiene and sanitation practices. To the best of our knowledge, this is the first of its kind comprehensive mobile phone intervention that enables data collection, counseling both face to face and through standard cell phone counseling messages and videos, and, provides automated delivery of tailored and timely text, voice and alert messages. The study is a demonstration project that will help explore the solutions needed in the ecosystem to enable and sustain the desired health and nutrition behavior change and how much it will cost the public health systems to achieve improved infant growth and development as enabled by a mobile phone-based[17]. Reducing child mortality with quality care is the prime-most concern of all nations. Thus in the current IT era, our healthcare industry needs to focus on adapting information technology in healthcare services. Barring few preliminary attempts to digitalize basic hospital administrative and clinical functions, even today in India, child health and vaccination records are still maintained as paper-based records. Also, error in manually plotting the parameters in growth charts results in missed opportunities for early detection of growth disorders in children. To address these concerns, we present India's first hospital linked, affordable automated vaccination and real-time child's growth monitoring cloud based application- Integrated Child HealthRecord cloud (iCHRcloud). This application is based on HL7 protocol enabling integration with hospital's HIS/EMR system. It provides Java (Enterprise Service Bus and Hibernate) based web portal for doctors and mobile application for parents, enhancing doctor-parent engagement[18]. A systematic review to determine if the use of nutrition apps resulted in improved outcomes, including knowledge and behavior, among healthy adults. Using app(s), cellular phone, iPads, mobile phone, mobile telephone, smart phone, mobile and mHealth as search terms with diet, food and nutrition as qualifiers. Inclusion criteria were peerreviewed randomized controlled trials, non-controlled trials, and cohort studies published in English that used apps to increase nutrition knowledge or improve behavior related to nutrition. Behavioral changes in reviewed studies included increased adherence to diet monitoring $(\mathrm{p}<0.001)$ and decreased effort to continue diet without app ( $\mathrm{p}<0.024)$. Few studies, however, have explored the use of nutrition apps as supportive educational interventions[19]. The use of online communities and websites for health information has proliferated along with the use of mobile apps for managing health behaviors. With respect to the comparisons between app users and non-users, we found no differences based on age, income, or education. This is in contrast with previous studies that found associations between younger age, higher education (more than high school), income and greater use of health-related apps. The study found that proportionately more women than men used mHealth apps. The links between self-rated smartphone skills, more frequent website use, and mHealth app use are to be expected given that these skills likely define the more digitally savvy users. Importantly, our results indicate that users of healthy lifestyle websites that also use mobile apps not only are more digitally competent but also have specific psychological needs predisposing them to use apps for managing their lifestyles[20]. To help reach populations of children without consistent Internet access or medical care, we designed and implemented Baby Steps Text, an automated text message-based screening tool. All post-study survey respondents agreed Baby Steps Text was understandable and easy to use, which was also confirmed through post-study interviews. Some survey respondents expressed liking Baby Steps Text because it was easy, quick, convenient to use, and delivered helpful, timely information. Our initial deployment study shows text messaging is a feasible tool for supporting parents in tracking and monitoring their child's development[21]. The smartphone users have used smartphone apps in daily life, few of them have used mental health themed smartphone apps. Given their interest, the development of customized smartphone apps may be promising direction for raising awareness of child mental health, delivering educational resources about child behavioral health, and increasing access to related services among an underserved Chinese immigrant community[22]. Patterns of eHealth use across a spectrum of individual/family and system level of eHealth interventions that can be applied to promote child mental health and strengthen mental health service systems[23]. Telemedicine is a technological tool that is improving the health of children around the world. This report chronicles the use of telemedicine by pediatricians and pediatric medical and surgical specialists to deliver inpatient and outpatient care, educate physicians and patients, and conduct medical research. It also describes the importance of telemedicine in responding to emergencies and disasters and providing access to pediatric care to remote and underserved populations. Barriers to telemedicine expansion are explained, such as legal issues, inadequate payment for services, technology costs and sustainability, and the lack of technology infrastructure on a national scale. Although certain challenges have constrained more widespread implementation, telemedicine's current use bears testimony to its effectiveness and potential. Telemedicine's widespread adoption will be influenced by the implementation of key provisions of the Patient Protection and Affordable Care Act, technological advances, and growing patient demand for virtual visits[24]. Nearly a quarter of families of children with need of subspecialty care report difficulty accessing that care. Telehealth is a method to overcome barriers to subspecialty care. However, improving access to subspecialty care through telehealth requires granular identification of specific subspecialty barriers and recognition of the strengths and limitations of each telehealth strategy for addressing 
identified barriers. Focusing on each sequential step in subspecialty referrals and potential associated barriers, we summarize specific telehealth and technology-enabled strategies to improve access to subspecialty care, including electronic consultations, live interactive telemedicine, storeand-forward telemedicine, tele-mentoring, patient portals, and remote patient monitoring. Intentionally selecting telehealth strategies to target specific subspecialty referral barriers may avoid risks from misapplication of telehealth, may more clearly elevate equitable access as an essential goal within telehealth initiatives, and may also lead to synergistic use of strategies that overcome sequential barriers[25].

\section{CONCLUSION}

MHealth effects to increase mother's skill in children growth development monitoring during $>36-48$ and $>48-60$ months.

\section{ACKNOWLEDGMENT}

The success and final outcome of this paper required a lot of guidance and assistance from many people and we extremely fortunate to have got this all along the completion of our paper. Whatever we have done is only do to such guidance and assistance and we would not forget to thank them. I respect and thank to Mr. Farid Husin for giving us opportunity to do this paper and providing us all support and guidance which made us complete the assignment on time. We extremely grateful to him for providing such a nice support and guidance.

We are grateful because we managed to complete this paper within the time given by Mr. Farid Husin. Last but not least, we would like to express our gratitude to our respondents for support and willingness to spend some time with us.

\section{REFERENCES}

[1] F. M. Diana, "Pemantauan perkembangan anak balita," pp. 116$129,2007$.

[2] Kemenkes RI, Laporan hasil Riset Kesehatan Dasar. Jakarta, 2013.

[3] Kemenkes RI, Pedoman pelaksanaan stimulasi, deteksi dan intervensi dini tumbuh kembang anak di tingkat pelayanan kesehatan dasar. 2013.

[4] S. Grantham-McGregor, Y. B. Cheung, S. Cueto, P. Glewwe, L. Richter, and B. Strupp, "Developmental potential in the first 5 years for children in developing countries," Lancet, vol. 369, no. 9555, pp. 60-70, 2007, doi: 10.1016/S0140-6736(07)60032-4.

[5] A. C. Figueiras, I. C. N. de Souza, V. G. Rios, and Y. Benguingui, Monitoring child development ( 0-6 Years) in the IMCI context. .

[6] D. H. Ulfani, D. Martianto, and Y. F. Baliwati, "Faktor-faktor sosial ekonomi dan kesehatan masyarakat kaitannya dengan masalah gizi underweight, stunted, dan wasted di Indonesia: Pendekatan ekologi gizi," J. Gizi dan Pangan, vol. 6, no. 1, p. 59, 2011, doi: 10.25182 /jgp.2011.6.1.59-65.

[7] L. S. Evangelista and M. A. Shinnick, "What do we know about adherence and self-care?," J Cardiovasc Nurs., vol. 23, no. 3, pp. 250-257, 2010 , 10.1097/01.JCN.0000317428.98844.4d.What

[8] D. Jongh, "Mobile phone messaging for facilitating selfmanagement of long-term illnesses ( Review )," Cochrane database Syst. Rev., vol. 12, no. 12, p. CD007459, 2012, doi 10.1002/14651858.CD007459.pub2.www.cochranelibrary.com.

[9] M. H. Satari and F. F. Wirakusumah, Konsistensi penelitian dalam bidang kesehatan. Bandung: PT Refika Aditama, 2011.

[10] A. Twissell, "Visualisation in applied learning contexts: A review," Educ. Technol. Soc., vol. 17, no. 3, pp. 180-191, 2014.

[11] H. Lin and F. M. Dwyer, "The effect of static and animated visualization: A perspective of instructional effectiveness and efficiency," Educational Technology Research and Development, vol. 58, no. 2. pp. 155-174, 2010, doi: 10.1007/s11423-009-9133-

[12] S. D. Richard, "Keterampilan ibu dalam deteksi dini tumbuh kembang terhadap tumbuh kembang bayi," J. STIKES, vol. 6, no. 1, pp. 63-73, 2013

[13] S. M. Love et al., "Social media and gamification: Engaging vulnerable parents in an online evidence-based parenting program," Child Abus. Negl., vol. 53, pp. 95-107, 2016.

[14] C. S. Bloss et al., "A prospective randomized trial examining health care utilization in individuals using multiple smartphoneenabled biosensors," PeerJ, vol. 2016, no. 1, pp. 1-16, 2016, doi: 10.7717/peerj. 1554 .

[15] M. Han and E. Lee, "Effectiveness of Mobile Health Application Use to Improve Health Behavior Changes: A Systematic Review of Randomized Controlled Trials," vol. 24, no. 3, pp. 207-226, 2018

[16] G. Rouleau, M. Gagnon, and J. Côté, "Impacts of information and communication technologies on nursing care: an overview of systematic reviews ( protocol )," BioMed Cent., pp. 1-8, 2015, doi: 10.1186/s13643-015-0062-y.

[17] A. B. Patel et al., "M-SAKHI-Mobile health solutions to help community providers promote maternal and infant nutrition and health using a community-based cluster randomized controlled trial in rural India: A study protocol," Matern. Child Nutr., vol. 15, no. 4, pp. 1-16, 2019, doi: 10.1111/mcn.12850.

[18] H. Singh, R. Mallaiah, G. Yadav, N. Verma, A. Sawhney, and S. K. Brahmachari, "iCHRCloud: Web \& Mobile based Child Health Imprints for Smart Healthcare," J. Med. Syst., vol. 42, no. 1, 2018, doi: 10.1007/s10916-017-0866-5.

[19] K. N. DiFilippo, W. H. Huang, J. E. Andrade, and K. M. ChapmanNovakofski, "The use of mobile apps to improve nutrition outcomes: A systematic literature review," J. Telemed. Telecare, vol. 21, no. 5, pp. 243-253, 2015, doi: 10.1177/1357633X15572203.

[20] S. Elavsky, D. Smahel, and H. Machackova, "Who are mobile app users from healthy lifestyle websites? Analysis of patterns of app use and user characteristics," Transl. Behav. Med., vol. 7, no. 4, pp. 891-901, 2017, doi: 10.1007/s13142-017-0525-x.

[21] H. Suh, J. R. Porter, R. Racadio, Y. C. Sung, and J. A. Kientz, "Baby Steps Text: Feasibility Study of an SMS-Based Tool for Tracking Children's Developmental Progress," AMIA ... Аnnu. Symp. proceedings. AMIA Symp., vol. 2016, pp. 1997-2006, 2016. E. Wu, J. Torous, and C. Liu, "Chinese immigrant use of smartphone apps toward improving child mental health awareness and resource delivery: A pilot study," Physiol. Behav., vol. 176, no. 3, pp. 139-148, 2019, doi: 10.1016/j.physbeh.2017.03.040.

[23] K. Y. Huang et al., "Use of Technology to Promote Child Behavioral Health in the Context of Pediatric Care: A Scoping Review and Applications to Low- and Middle-Income Countries," Front. Psychiatry, vol. 10, no. November, 2019, doi: 10.3389/fpsyt.2019.00806.

[24] S. A. Spooner, E. M. Gotlieb, and C. I. Technology, "Telemedicine: Pediatric applications," Am. Acad. Pediatr., vol. 113 , no. 6, 2004.

[25] K. N. Ray and J. M. Kahn, "Connected Subspecialty Care: Applying Telehealth Strategies to Specific Referral Barriers," Acad. Pediatr., vol. 000, pp. 1-7, 2019, doi: 10.1016/j.acap.2019.08.002 